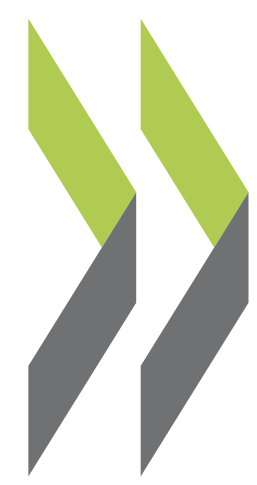

CELE Exchange, Centre for Effective Learning Environments 2010/01

\title{
OECD Review \\ of the Secondary School Modernisation Programme in Portugal
}

\section{Alastair Blyth}

https://dx.doi.org/10.1787/5kmh36jdchmn-en 


\section{POECD review of the secondary school modernisation programme in Portugal}

\section{By Alastair Blyth, OECD}

On 26 February in Lisbon a team from the OECD's Centre for Effective Learning Environments (CELE) presented its first review of a national school building programme.

The school building renovation programme in Portugal, which began in March 2007, involves the renovation of 332 schools by 2015. However, Portugal plans to complete 205 by the end of 2011, spending EUR 2.45 billion to do so.

The review, which took place last summer, presented CELE with an opportunity to evaluate the programme drawing on the collective knowledge and experience of both experts and members of the CELE Board of Participants. It also provided a focus for CELE members to discuss issues that affect them all, from managing a programme of wholesale renewal to identifying the kinds of spaces that support teaching and learning. The report was released in December.

The programme in Portugal aims to tackle the physical deterioration of the building stock and environmental standards in terms of energy performance. It will address environmental comfort, sanitary standards and the functional inadequacy of the buildings for teaching and learning. It also aims to open up the schools to the local community, and include long-term maintenance of the buildings after modernisation.

\section{BACKGROUND TO THE PROGRAMME}

As part of a broader focus on education and its delivery in Portugal, the Portuguese government has recognised that school buildings play an important role in improving the standards of education. In the Resolution of the Council of Ministers, in which the government approved the plans for the modernisation programme, it stated its belief that the quality of school buildings make a crucial contribution to educational achievement. However, several surveys of school facilities carried out in the last decade reveal the extent to which the quality of school buildings in Portugal had deteriorated. So much so that they no longer provided environments conducive to contemporary education.

The programme is addressing this concern by renovating and upgrading the schools. Its ultimate goal is to provide the Portuguese educational system not just with state-of-the-art school buildings, but with a new approach to the way the community sees schools. An important component of the modernisation strategy is that it includes maintaining the schools once they have been renovated. 
To deliver the programme, the Portuguese government set up an independent state-owned company in January 2007. This organisation, Parque Escolar, is responsible for planning and managing the modernisation programme, and has been given both administrative and financial autonomy. This means that it can take a commercial approach to managing both the procurement and maintenance of schools. As it is neither the designer nor construction contractor, it appoints architects and building contractors for specific projects. The company is closely supervised by the ministries of education and finance.

The programme is being carried out in phases. The pilot phase consisted of four schools. Phase I of the main programme consisted of 26 schools; Phase II of 75 schools; and Phase III of 100 schools. The remaining schools will follow on. The process involved in modernising each school is relatively traditional. Schools are selected for each of the main phases of the modernisation programme not only on the basis of their condition, but also on the basis of projected enrolments and the views of the regional education authorities.

During the pre-design stage of the school project, the school develops a strategic plan which brings together the school's vision, pedagogical approach and main educational goals. The information from the strategic plan is used to develop a functional programme and list of spaces required which are then given to the architects for them to start their design work.

During the construction phase the building contractor carries out the work, supervised by a separate company. This supervisor makes sure that the contractor follows the contract and oversees on-site safety procedures. It also oversees any input from the design team that is needed during construction and coordinates with the school.

Once the construction work has finished, ownership of the school facilities is transferred from the state to Parque Escolar, which is then responsible for carrying out the maintenance and renewal of the school facilities and equipment. In return, Parque Escolar receives a rent based upon the amount of space available for use by the school. For areas of a school that are not yet available, Parque Escolar will be subject to a "non-availability" penalty.

Escola Secundária de Benavente

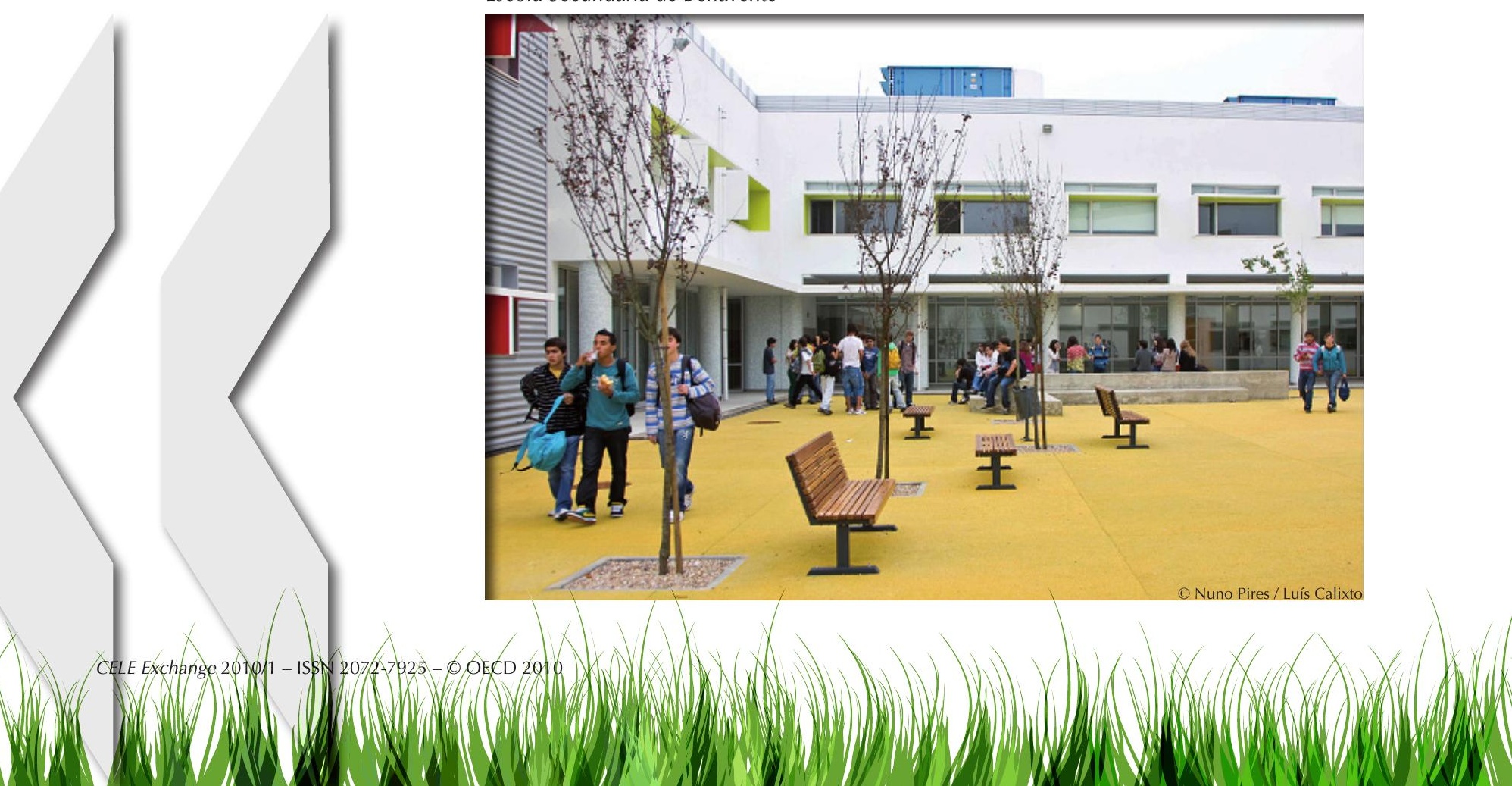




\section{THE REVIEW}

The OECD carries out many reviews within countries, of specific programmes or policy areas. Indeed the OECD's Directorate for Education has recently carried out a review in Portugal of teacher evaluation. This is the first time that CELE has reviewed a school building programme.

The review team consisted of five experts: four were external and one a member of the OECD Secretariat. The aim was to create a team with varied expertise. The experts had skills and experience ranging from national and local government policy implementation, teaching, educational policy implementation, schools architecture and procurement.

Based on background information provided by the ministry of education, the review team visited Portugal for one week. It interviewed a range of officials from the ministry of education, regional authorities, unions, schools leaders, as well as school principals, teachers, staff, students and parents. It also visited seven schools, some completed and some under construction.

The draft report on the review was discussed with experts and representatives from Portugal at a meeting of the CELE Board of Participants, after which the final version was released.

However, no less important than the report is the process of the review itself and the opportunity it gives the country to reflect on what it is doing and make any changes. This was certainly evident in this exercise as Portugal continuously updated guidelines and other processes in light of discussions with the review team.

The aim of the review was to produce an objective assessment and evaluation of the effectiveness of the programme. It focused on:

- The performance of the programme and in particular how it addresses the physical quality of school buildings; the suitability of the facilities for current and future needs and whether there are sufficient spaces to meet the needs; and how stakeholders are engaged in the process.

- How the programme can better meet Portugal's strategic objectives for secondary education.

- Whether and how the overall programme should be rationalised.

- The governance structure of the programme and the relationship between Parque Escolar, national educational authorities, school institutions and other stakeholders.

- The funding mechanisms, levels of funding available, and the efficiency with which resources are used.

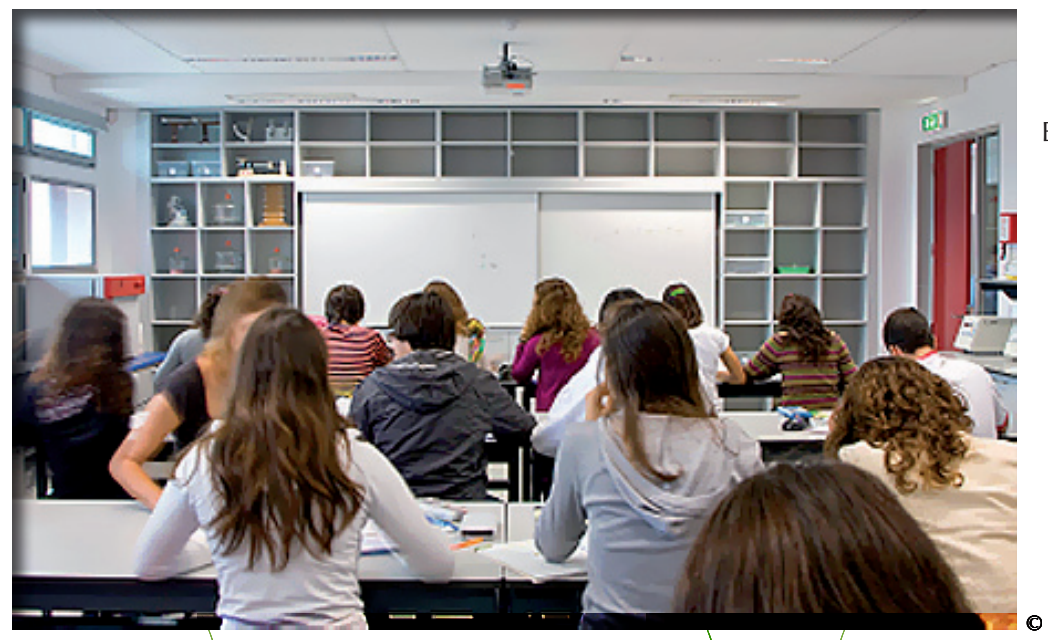

Escola Secundária de Benavente 


\section{FINDINGS OF THE REVIEW}

The report discusses in detail the findings of the review. However, it is worth highlighting some of the strengths, challenges and opportunities here.

Much has been achieved in improving the quality of the schools. The strategy of starting the programme with four pilot projects that represented different school types provided much valuable insight for the programme as a whole. The creation of a single organisation to manage and deliver the programme has also been beneficial. The strategy of including long-term maintenance as a fundamental component of the project is critical to achieving the objectives of creating a sustainable education building stock that meets the long-term needs of education.

The programme has political support from the highest level in the country, but also support throughout the system from the unions, teachers, parents and students. The goodwill and ambition of course means that expectations are high. The programme benefits from a conjunction of circumstances, which at the same time is driving the speed of events. Together, the political will, availability of funding from the EU and a climate encouraging investment in public works to offset the effects of recession have enabled Portugal to make this significant investment.

Although these achievements are significant, there are some challenges. The speed at which the programme is being unfolded means that there is limited scope for applying lessons learned along the way. A lot therefore depends on getting things right first time.

The report also notes the importance of consultation and stakeholder involvement which, at local level, appeared more successful than at national level.

While the quality of the buildings has radically improved, the design of the spaces often appeared to be conventional with, for example, similar sized classrooms. There is perhaps scope for more innovation in the provision of different spatial configurations to provide a greater range of spaces for different educational needs.

The ease with which furniture layouts can be altered impacts on the flexibility of the spaces. The use of flexible furniture in, for example, the science laboratories do offer the opportunity for different teaching styles. Indeed the science experts employed by Parque Escolar have spent considerable amounts of time tutoring science teachers on how they can change the furniture arrangements in the classroom to teach in different ways. This latter point suggests a further role for Parque Escolar beyond managing the maintenance of the buildings once construction has finished. The company's experience in the design and use of space to support educational needs can be used to provide advice to the directors of schools and teachers as they try to find innovative ways of using their buildings.

Having invested significant resources in this modernisation programme, in many senses it is a oneoff. However, it does raise the question as to what investment there should be in those schools currently not thought to be in need of modernisation but which at some point in the future may need attention. The programme has generated a lot of experience and knowledge which will be useful for the future. 
The review has provided an opportunity for CELE and its members to reflect on the many issues from funding to use. The value in this is that while not all countries are carrying out such a large programme, many of the issues are relevant to individual projects. Portugal was the focus of this review, but the other members of CELE have benefitted from it too.

To access the review report, please visit: www.oecd.org/edu/facilities.

For more information, contact:

Alastair Blyth

Analyst

OECD Centre for Effective Learning Environments

Organisation for Economic Co-operation and Development

2, rue André-Pascal

75775 Paris Cedex 16

France

E-mail: alastair.blyth@oecd.org www.oecd.org/edu/facilities 


\section{ORGANISATION FOR ECONOMIC CO-OPERATION AND DEVELOPMENT}

The OECD is a unique forum where the governments of 30 democracies work together to address the economic, social and environmental challenges of globalisation. The OECD is also at the forefront of efforts to understand and to help governments respond to new developments and concerns, such as corporate governance, the information economy and the challenges of an ageing population. The Organisation provides a setting where governments can compare policy experiences, seek answers to common problems, identify good practice and work to co-ordinate domestic and international policies.

The OECD member countries are: Australia, Austria, Belgium, Canada, the Czech Republic, Denmark, Finland, France, Germany, Greece, Hungary, Iceland, Ireland, Italy, Japan, Korea, Luxembourg, Mexico, the Netherlands, New Zealand, Norway, Poland, Portugal, the Slovak Republic, Spain, Sweden, Switzerland, Turkey, the United Kingdom and the United States. The Commission of the European Communities takes part in the work of the OECD.

OECD Publishing disseminates widely the results of the Organisation's statistics gathering and research on economic, social and environmental issues, as well as the conventions, guidelines and standards agreed by its members.

This work is published under the responsibility of the Secretary General of the OECD. The opinions expressed and arguments employed herein do not necessarily reflect the official views of the Organisation or of the governments of its member countries.

You can copy, download or print OECD content for your own use, and you can include excerpts from OECD publications, databases and multimedia products in your own documents, presentations, blogs, websites and teaching materials, provided that suitable acknowledgment of OECD as source and copyright owner is given. All requests for public or commercial use and translation rights should be submitted to rights@oecd.org. Requests for permission to photocopy portions of this material requests for public or commercial use and translation rights should be submitted to rights@oecd.org. Requests for permission to photocopy portions of this material
for public or commercial use shall be addressed directly to the Copyright Clearance Center (CCC) at info@copyright.com or the Centre français d'exploitation du droit de copie (CFC) contact@cfcopies.com. 